\title{
Onsite Reuse of Reclaimed Wastewater in Winter to Determine Potential for Pollutant Runoff
}

\author{
JOSHUA GRIFFIN, Water Quality Modeling, Ohio Environmental Protection Agency, Columbus, OH, USA; and KAREN M. \\ MANCL', Department of Food, Agricultural and Biological Engineering, The Ohio State University, Columbus, OH, USA.
}

\begin{abstract}
The objectives of this study were to determine the impact of reclaimed wastewater irrigation in freezing conditions on the quality of runoff and to observe how soils respond to irrigation in freezing temperatures. Onsite irrigation systems were constructed on 6 bermed lots on a hillside in Coshocton County, Ohio. All runoff was collected in gutters at the bottom of the hill. Two lots were irrigated with artificial reclaimed wastewater, 2 with well water, and 2 were unirrigated. Runoff was collected through an average winter (2013) and a severe winter (2014). The infiltrative capacity of the plots was maintained during the average winter and yielded runoff on only one day. During the severe winter, runoff occurred on 11 days; of the regulated pollutants, only ammonia was significantly higher than the control plots. The volumes that ran off were lower than what was applied and the contaminate concentrations were lower than what was applied and did not exceed National Pollutant Discharge Elimination System (NPDES) effluent limits. The indication is that even in the worst-case scenario most of the pollutants were assimilated on site.
\end{abstract}

\section{INTRODUCTION}

Discharges of pollutants to surface waters in the United States degrade water quality. Amendments to the Federal Water Pollution Control Act in 1972, better known as the Clean Water Act (USEPA 2015), established the National Pollutant Discharge Elimination System (NPDES). The NPDES governs the discharge of pollutants from point sources to surface waters. The NPDES permitting system was created to incrementally move towards the goal of eliminating pollutants from point sources.

Wastewater irrigation can meet the national goal of eliminating discharge and has the potential to benefit water resources because wastewater is reintroduced to the environment. The soil is a living filter that can provide tertiary treatment to effluent as it moves through the soil to surface waters or into the groundwater network. Conventional pollutants, including biochemical oxygen demand, ammonia, solids, and pathogens are removed prior to irrigation. Then, the soil provides tertiary treatment to further reduce pollutants, including the nutrients of nitrogen and phosphorus.

Irrigation in cold weather has the potential to stress the irrigation infrastructure as well as the plants growing in the irrigated area. The impact of year-round irrigation on landscape plants in Ohio was studied

${ }^{1}$ Address correspondence to Karen M. Mancl, Department of Food, Agricultural and Biological Engineering, The Ohio State University, 590 Woody Hayes Dr., Columbus, OH 43210. Email: mancl.1@osu.edu by Caldwell et al. (2007). They observed positive impacts on plant varieties that require a dormancy period in the winter months. Some plant species, especially fine-needle evergreens, were damaged by winter-applied wastewater. Gunn and Mancl (2011) studied alternative means of sprinkler drainage to reduce stress on the irrigation infrastructure. They found that if sprinklers were drained they did not break. However, sprinklers operated under freezing conditions experienced a rotational delay and then functioned normally.

The additional water added through irrigation could alter the soil's structure. Sopper and Richenderfer (1978) examined soil structure after wastewater was seasonally applied on the irrigation fields for 12 years. Significant differences were observed in soil physical properties compared to control sites at similar landscape positions with the same vegetative cover. Walker and Lin (2008) examined soil physical properties after four decades of year-round irrigation. They stratified the results by landscape position. Significant changes were found that would affect the soil's interaction with irrigated wastewater. The largest increase in bulk density and decrease in saturated hydraulic conductivity occurred in the summit areas. The largest increase in redoximorphic features occurred in depressional areas. Despite these changes, they concluded that after 4 decades the soil had maintained adequate infiltration capacity for wastewater applications. 
The potential for pollutant runoff remains a concern when wastewater is irrigated under freezing conditions. A study in Vermont (Jewell and Swan 1975) irrigated steep slopes that were known to have a shallow impermeable layer that resulted in seasonally elevated water tables. The system was observed throughout the winter and runoff was not observed during irrigation. However, when snowmelt occurred in the spring, runoff was noted.

An irrigation system in Michigan was observed by $\mathrm{Hu}$ et al. (2005) focusing on the ability of the soils on the site to remove phosphorus from the effluent. The irrigated soils were initially of poor quality and had minimal cation exchange capacity that could react with and remove phosphorus. The irrigation resulted in an increase in the capacity of the soils to remove phosphorus after 30 years of application. This was largely attributed to the increase in soil calcium and organic matter.

Surface irrigation has shown promise in many ways for wastewater reclamation and the elimination of pollutant discharge. However, for it to be feasible at the household scale, year-round irrigation through freezing conditions will be necessary. This study had 2 objectives. The first was to determine the impact of reclaimed wastewater irrigation-in freezing conditions-on the quality of runoff. The second was to observe how the soils respond to irrigation-again in freezing temperatures-in a climate with multiple freeze-thaw cycles per year.

\section{MATERIALS AND METHODS}

The North Appalachian Experimental Watershed facility consisted of 420 hectares in Coshocton County, Ohio. The facility was developed in the 1930s and specialized in plot-scale to small-watershed research. The station maintained 6 lawn-scale plots shown in Fig. 1.

The plots were 0.11 to 0.15 ha and were bermed so all runoff would be captured by a gutter on the downslope end (Fig. 2A). The plots were south-facing and had approximately a $10 \%$ slope increasing slightly when moving in an easterly direction across the hillside.

The gutter channeled runoff through a tipping flow meter bucket and a proportional sample of $50 \%$ was diverted into a secondary sample collection building (Fig. 2B).

Soil freezing was monitored using electromagnetic sensors. Sensors monitored both soil temperature and soil moisture. The soil moisture sensors were Decagon

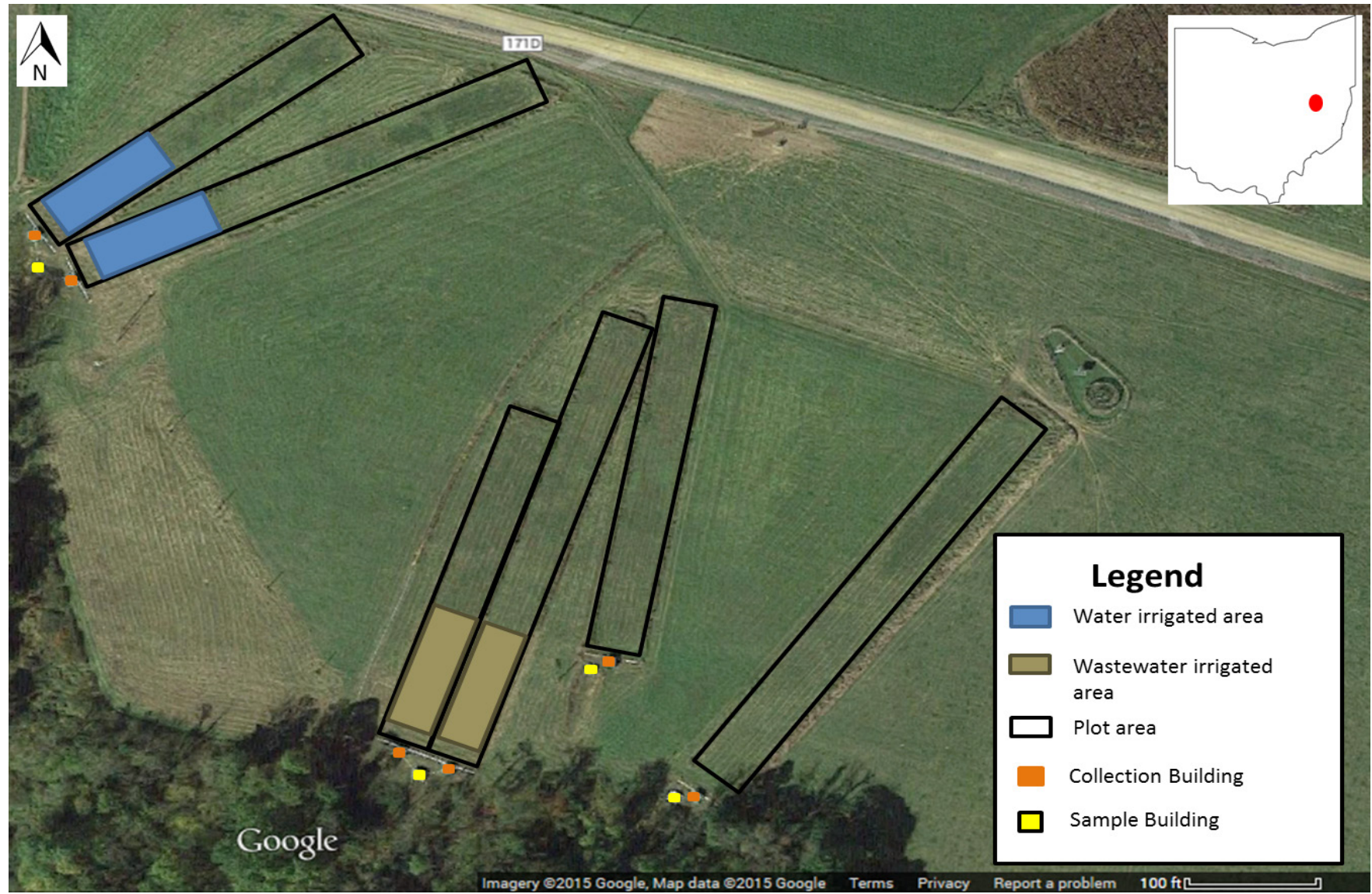

FIGURE 1. Aerial image of the test plots at the North Appalachian Experimental Watershed in Coshocton County, Ohio, with irrigation areas and key infrastructure identified 

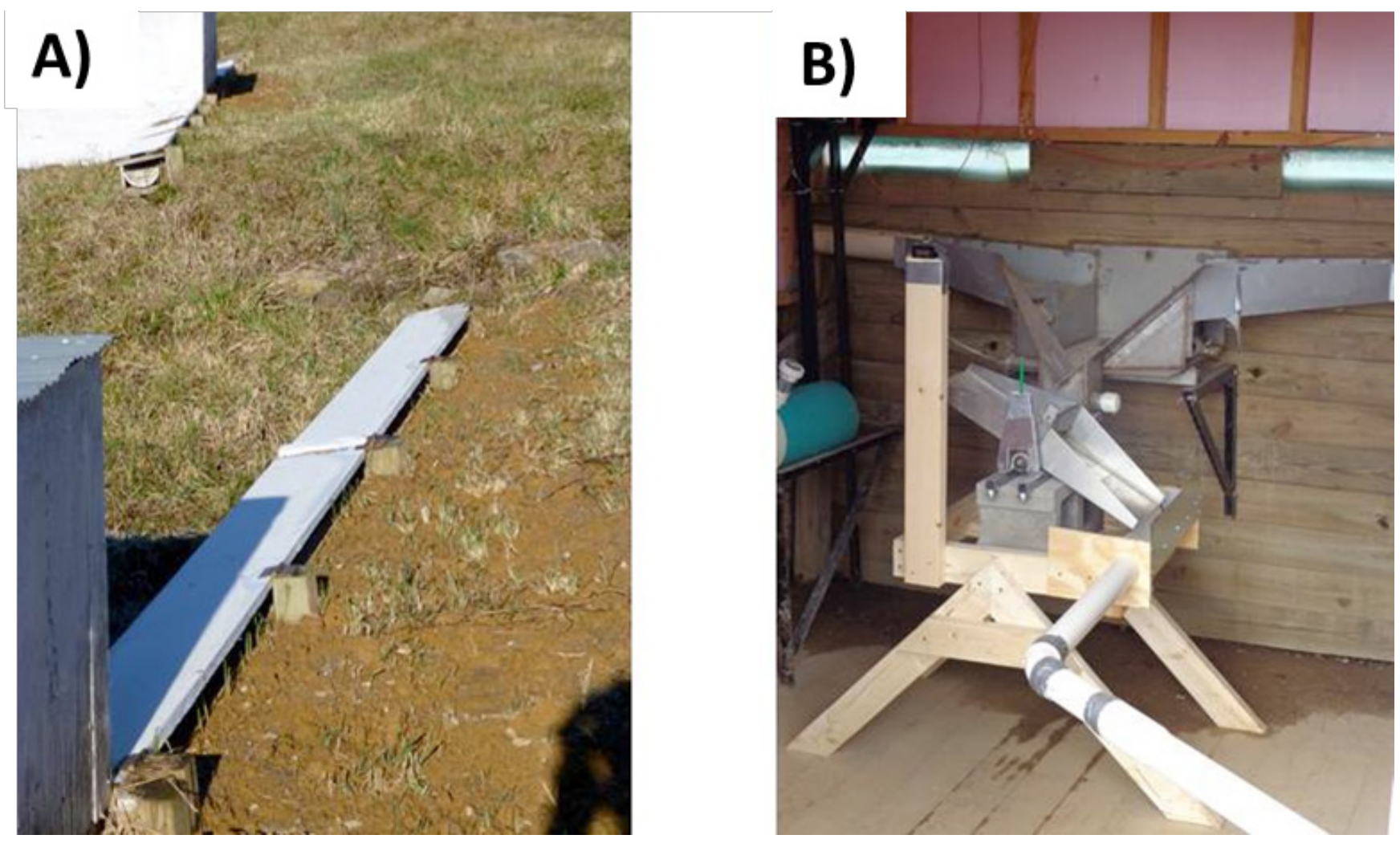

FIGURE 2. Two parts of the runoff collection system. A) the runoff collection gutters installed at the downslope edge of each test plot, and $\mathrm{B}$ ) the tipping flow meter bucket connected to the runoff collection gutters at each test plot. Half of the water that flowed through the tipping bucket was diverted to a large sample collection container (not pictured).

EC-5 sensors (Decagon Devices 2014) coupled with Em50 dataloggers. Temperature sensors used were Onset $^{\circledR}$ TMC20-HD sensors coupled with $\mathrm{HOBO}^{\circledR}$ U-series 4-channel dataloggers. The moisture sensors were deployed at 2.5 and $7.5 \mathrm{~cm}$ with temperature sensors at 2.5, 7.5, 15, and $22.5 \mathrm{~cm}$ depth (Fig. 3). Each plot had two monitoring points.

Runoff samples were analyzed for 5-day biochemical oxygen demand $\left(\mathrm{BOD}_{5}\right)$, total suspended solids (TSS), total nitrogen $(\mathrm{TN})$, total phosphorus (TP), ammonia $\left(\mathrm{NH}_{3}-\mathrm{N}\right)$, nitrate $\left(\mathrm{NO}_{3}-\mathrm{N}\right)$, and phosphate $\left(\mathrm{PO}_{4}-\mathrm{P}\right)$ (Clesceri et al. 1998). E. coli was measured in runoff samples as an indicator of microbial pollution (USEPA 1986).

The six plots were paired and split into three different

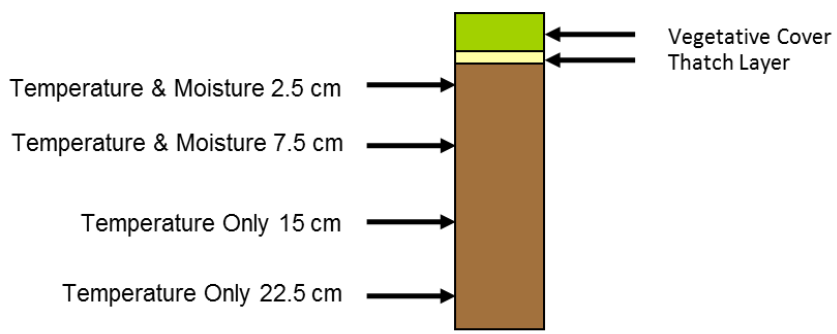

FIGURE 3. Cross-section illustrating sensor installation, indicating the depths the temperature and moisture sensors were placed in the soil profile treatments: two plots (one 0.11 ha plot and one 0.15 ha plot) were irrigated with well water, two plots (one 0.11 ha plot and one 0.15 ha plot) were irrigated with simulated wastewater, and two plots (one 0.11 ha plot and one 0.15 ha plot) were not irrigated as a control. The irrigation systems were designed with the specifications recommended by Rowan et al. (2004). The setback was $3 \mathrm{~m}$ (10 feet) from any ditch or surface waterbody, so the irrigation zone started that distance upslope from the gutters. The irrigation zone was designed to cover 0.03 ha (3000 square feet) with 4 sprinklers applying $5.1 \mathrm{~mm}$ (0.2 inches) of water to the irrigated area $(1361 \mathrm{~L})$.

Goulds ${ }^{\circledR}$ effluent pumps were used to pressurize the system irrigating at approximately $45.4 \mathrm{~L} / \mathrm{min}$ at $276 \mathrm{kPa}$. None of the irrigation system's layouts were exactly identical, so the runtime of each irrigation system was calibrated to deliver the $1361 \mathrm{~L}$ dose. Each plot received an irrigation dose every other day. The sprinklers used were Rain Bird ${ }^{\circledR}$ 3500-SAM models spraying inward to the plots and applying water in a pattern of overlapping semi-circles. The irrigation zone represented $25 \%$ and $19 \%$ of the 0.11 and 0.15 ha plots, respectively.

Simulated treated wastewater was prepared with the goal to be near or above the NPDES discharge 
limit. By making simulated treated wastewater, quality could be controlled and be more constant throughout the winter. To produce simulated wastewater in 2013 , 1 part of dairy manure was added per 1000 parts of well water by volume to the tank serving the 2 plots. The pollutant concentration in the simulated treated wastewater used in the 2013 season is in Table 1. E. coli bacteria levels in the simulated treated wastewater ranged from 16,800 to $54,500 \mathrm{cfu} / 100 \mathrm{~mL}$, which was intentionally much higher than the regulatory limit for irrigated wastewater of $530 \mathrm{cfu} / 100 \mathrm{~mL}$.

In 2014, the simulated wastewater was modified based on information gathered during the 2013 season. The dairy manure had a high fiber content that was difficult to screen out when mixed into the tank. Instead, lower fiber swine manure was used. Because the simulated wastewater produced in year 2013 had total phosphorus and total nitrogen lower than the target, these soluble nutrients were added to the 2014 wastewater mixture to targets of $15 \mathrm{mg} / \mathrm{L}$ $\mathrm{N}$ and $5 \mathrm{mg} / \mathrm{L} \mathrm{P}$. The simulated wastewater used in the 2014 season is presented in Table 2.

\section{RESULTS}

The experiment took place over two winters: January 21, 2013 to May 1, 2013 for 100 days and December 1, 2013 to April 30, 2014 for 151 days. Environmental conditions and runoff quality were monitored throughout the duration of the experiment.

\section{Weather Conditions}

Weather was an uncontrolled parameter and was monitored throughout the experiment. The weather during the experiment was summarized on a monthly basis and compared to monthly normal values in Table 3. Local temperatures were measured at a weather station (Station: OH Coshocton 8 NNE) that is part of the Climate Reference Network (CRN) administered by the National Oceanic and Atmospheric Administration (NOAA).

Comparing the monthly temperature data to the normal for the same location highlights the near normal winter weather of 2013 and the severe winter experienced in 2013-14. Temperatures for December 2013 to March 2014 were colder than the normal. The monthly precipitation totals generally reflect the

Table 1

Samples $(\mathrm{N}=3)$ to characterize pollutant concentrations in 2013 simulated treated wastewater

Wastewater mixture: dairy manure and well water

(all units are in $\mathrm{mg} / \mathrm{L}$ )

\begin{tabular}{crrccccc}
\cline { 2 - 7 } Sample date & $\mathrm{BOD}_{5}$ & $\mathrm{TSS}$ & $\mathbf{N H}_{3}-\mathbf{N}$ & Total-N as $\mathbf{N}$ & Total-P as $\mathbf{P}$ & $\mathbf{P O}_{4}-\mathbf{P}$ & $\mathbf{N O}_{3}-\mathbf{N}$ \\
\hline $3 / 2 / 13$ & 9.3 & 73 & 0.8 & 3.46 & 0.67 & 0.31 & 0.62 \\
$3 / 16 / 13$ & 10.1 & 122 & 0.65 & 1.7 & 1.05 & 0.8 & $<0.01$ \\
$3 / 24 / 13$ & 20.4 & 111 & 0.72 & $<0.01$ & 0.94 & 0.51 & $<0.01$ \\
Average & 13.3 & 102 & 0.72 & 1.72 & 0.89 & 0.54 & 0.21 \\
Target & $>10$ & $>30$ & $>3.0$ & - & - & - & - \\
\hline
\end{tabular}

Table 2

Samples $(\mathrm{N}=3)$ to characterize pollutant concentrations in 2014 simulated treated wastewater

Wastewater mixture: swine manure, well water, and added soluble nutrients (all units are in $\mathrm{mg} / \mathrm{L}$ )

\begin{tabular}{cccccccc}
\cline { 2 - 7 } Sample date & $\mathrm{BOD}_{5}$ & $\mathrm{TSS}$ & $\mathrm{NH}_{3}-\mathbf{N}$ & \multicolumn{1}{c}{ Total-N as $\mathbf{N}$} & Total-P as $\mathbf{P}$ & $\mathbf{P O}_{4}-\mathbf{P}$ & $\mathbf{N O}_{3}-\mathbf{N}$ \\
\hline $1 / 4 / 14$ & - & 268 & 3 & 18 & 4.94 & 4.67 & 13.5 \\
$3 / 9 / 14$ & 20.25 & 93 & 3.97 & 5.85 & 3.64 & 3.37 & 3.85 \\
$4 / 12 / 14$ & 11.7 & 148 & 13.9 & 11.3 & 3.74 & 3.85 & 2.67 \\
Average & 16 & 170 & 7 & 12 & 4.11 & 3.96 & 6.67 \\
Target & $>10$ & $>30$ & $>3.0$ & 15 & 5.0 & - & - \\
\hline
\end{tabular}


Table 3

Monthly temperature and precipitation as normal values and monthly averages monitored during 2013 and 2014 winter seasons ${ }^{a}$

\begin{tabular}{|c|c|c|c|c|c|c|}
\hline \multirow[b]{2}{*}{ Month } & \multicolumn{3}{|c|}{ Average temperature $\left({ }^{\circ} \mathrm{C}\right)$} & \multicolumn{3}{|c|}{ Total precipitation (mm) } \\
\hline & Normal & 2013 & 2014 & Normal & 2013 & 2014 \\
\hline December & -0.04 & -0.1 & - & 69.6 & 84 & - \\
\hline January & -2.9 & -0.9 & -6.9 & 63.8 & 45.6 & 37.3 \\
\hline February & -1.2 & -2.1 & -4 & 52.8 & 55.2 & 51.5 \\
\hline March & 3.7 & 1.6 & 0.3 & 74.2 & 61.8 & 52.7 \\
\hline April & 10.4 & 10.7 & 11.3 & 86.4 & 82.6 & 138.3 \\
\hline
\end{tabular}

normal values with the biggest anomalies occurring during the especially dry January of 2014 and an especially wet April of 2014. The monthly normal values were more useful in describing the moisture condition so additional temperature analysis was done to describe the nature of freezing conditions during the two seasons.

"Freezing events" were defined as times when the daily average air temperature was below freezing. The daily average air temperatures in the 2014 winter season included more extreme cold temperatures than the 2013 season. However, the difference that had the greatest impact during the experiment was the duration of freezing events observed. The 2014 season was dominated by long durations where air temperatures remained below freezing. Fig. 4 shows the count and duration of freezing events observed in the 2013 and 2014 season.

While the 2014 season had fewer overall events, the longest five events were longer than their counterparts from the 2013 season. Also of note, the two longest events from the 2014 season were separated by a single day. In an event of this magnitude a single day was unable to drive a complete thaw and, effectively, freezing conditions persisted for 35 days in the 2014 season.

\section{Soil Freezing}

Soil freezing was monitored in all three treatments

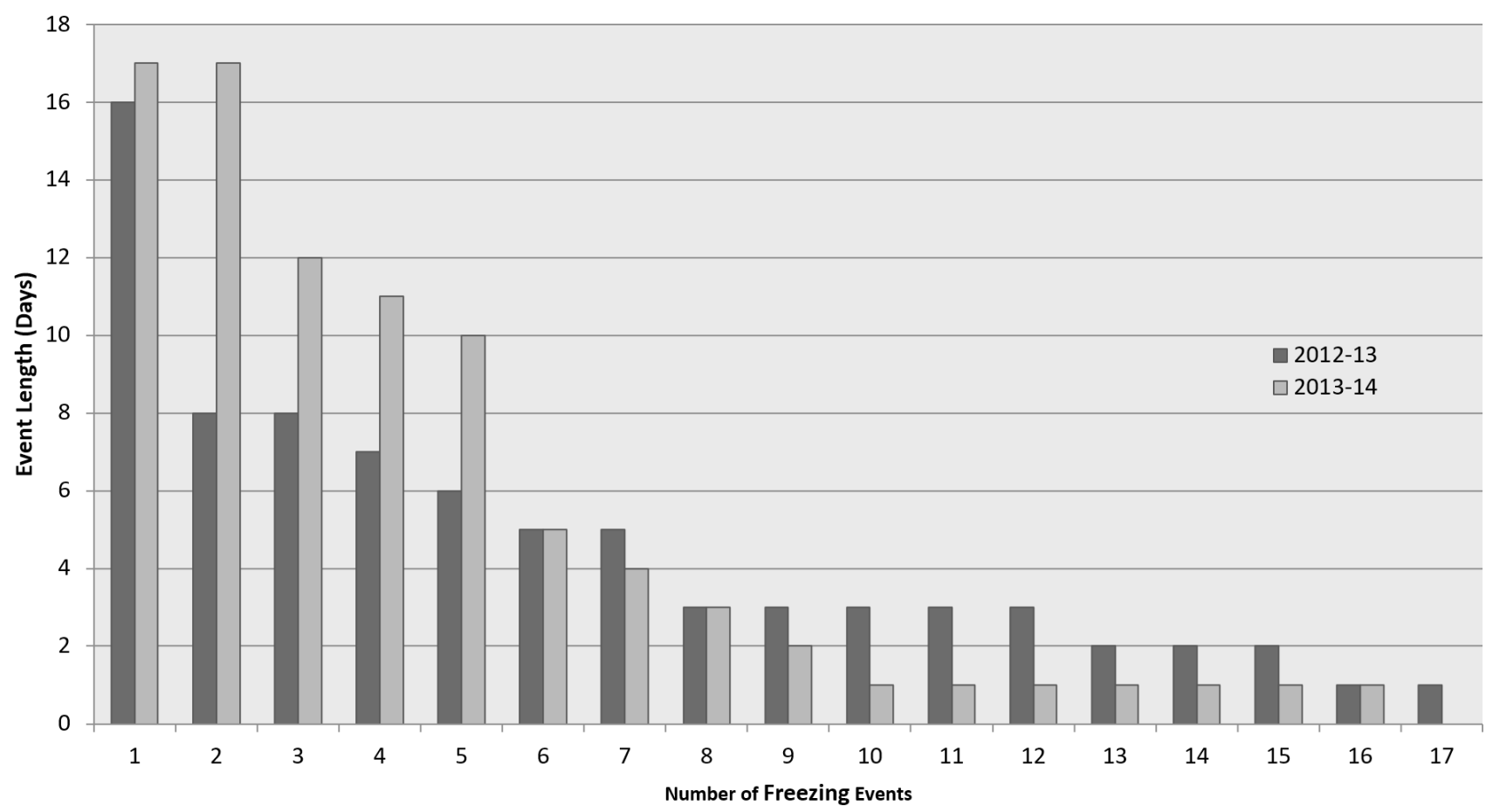

FIGURE 4. Freezing event length for the two winter seasons. Freezing events are identified as times when the air temperature did not exceed $0{ }^{\circ} \mathrm{C}$. 


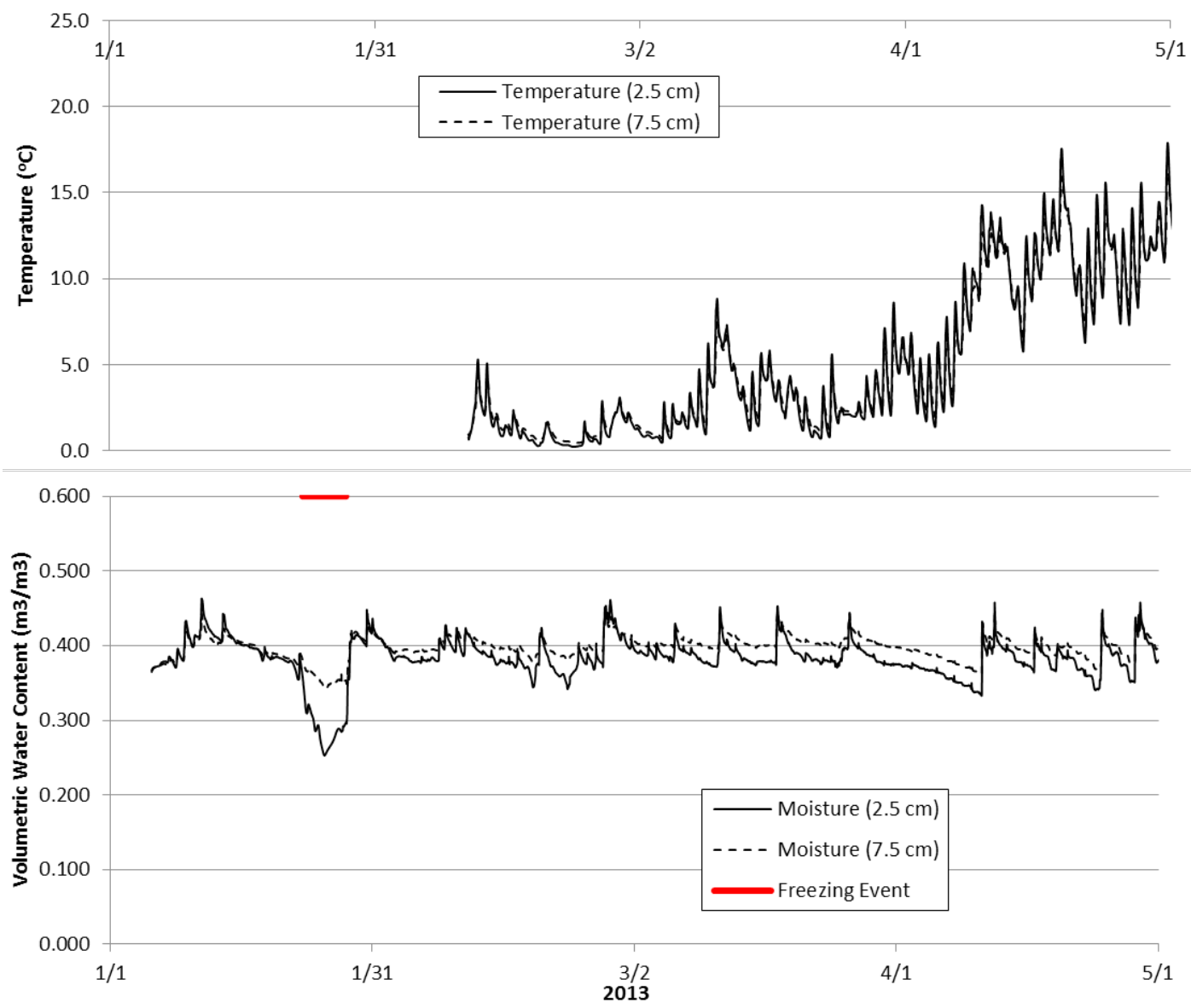

FIGURE 5. Soil moisture and soil temperature from the 2013 winter irrigation season. Freezing events are identified when soil moisture declines as liquid water turns to ice. No soil temperature data was available at the time of the single soil freezing event.

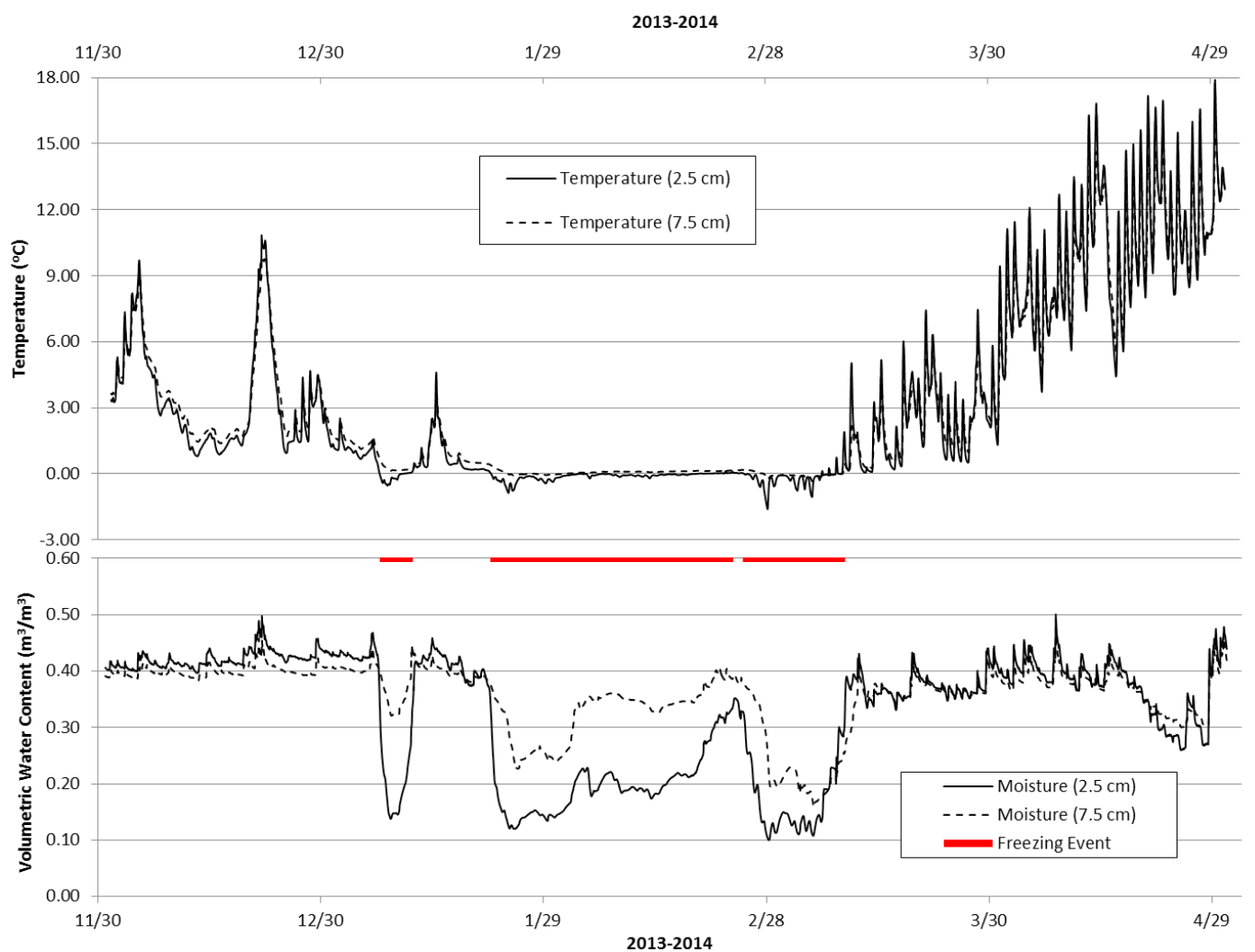

FIGURE 6. Soil moisture and soil temperature from the 2014 winter irrigation season. Freezing events are identified when soil temperatures were at or below freezing and soil moisture declines as liquid water turns to ice. Three distinct soil freezing events were observed. 
to provide information across the landscape. Soil temperature and moisture data from two winters of irrigation is presented in Fig. 5 and Fig. 6. Soil freezing events are identified on the plots. To have a soil freezing event identified, two trends had to be present: 1) soil temperature was at or below freezing; and 2) a sharp drop in soil moisture was observed.

During the first winter, soils only froze one time at a $2.5 \mathrm{~cm}$ depth. However, the event was only identified with soil moisture data because temperature sensors were inactive at the time. The freezing event corresponded to the first week of irrigation. During the second winter, three distinct freezing events were identified. The first was a complete freeze followed by a complete thaw at $2.5 \mathrm{~cm}$ which lasted 5 days. The freezing was not as complete at $7.5 \mathrm{~cm}$, as noted with a lesser drop in soil moisture indicating less ice content. The second lasted 33 days and spanned multiple air freezing events without completely thawing. The latter portion of the second event represented partially frozen soils that were near $0{ }^{\circ} \mathrm{C}$ representing isothermal conditions. During the second freezing event the 7.5 $\mathrm{cm}$ depth was never completely frozen. Rather it was in an isothermal condition during the entire event with some ice and some water at or near $0{ }^{\circ} \mathrm{C}$. The third event demonstrated the most complete freeze across the landscape and directly followed an incomplete thaw from the second event. The third event also showed the most complete freezing at $7.5 \mathrm{~cm}$. Soil temperature was similar at both monitoring depths and differences were not readily observed when soil temperatures were above freezing. The soil temperatures at the two depths diverged during freezing events when soil temperatures at the shallower monitoring point typically got colder than the deeper point.

\section{Runoff Quality}

During the "normal" winter of 2013, a total of 0.117 $\mathrm{kg}$ of total nitrogen and $0.06 \mathrm{~kg}$ of total phosphorus was applied to the treated wastewater irrigated sites.
Runoff was onlyobserved in one instance. In that event, enough runoff was captured to conduct water quality analysis from two plots; one which was irrigated with treated wastewater and one which was irrigated with water. During this event, small quantities of runoff were collected $(<20 \mathrm{~L})$. The water quality from these samples is presented in Table 4. Due to the single observation, a statistical comparison between the samples was not possible. In the runoff event only 82 mg of total nitrogen and $3.2 \mathrm{mg}$ of total phosphorus ran off the treated wastewater irrigated site over the 100-day experiment during a normal winter. Also, the magnitude of pollutants from the sample on the water plot was always greater than the wastewater plot.

During the "severe" winter of 2014, a total of 0.88 $\mathrm{kg}$ of total nitrogen and $0.38 \mathrm{~kg}$ of total phosphorus were applied to the treated wastewater irrigated sites over the 151-day experiment. Runoff was collected on a total of 11 days. Runoff occurred from the treated wastewater plots on a total of 8 days in February and March and from the control plots on a total of 8 days in December, February, March, and April. Unfortunately, due to equipment malfunctions, the total runoffvolume was not always recorded. No runoff was collected from the water irrigated plots that year due to the development of preferential flow pathways, which directed water around the runoff collection troughs. Therefore, only the 2014 wastewater and control plots are shown in Table 5. A statistical comparison ( $\alpha=$ $0.05)$ is presented in Table 6.

Across the 2014 runoff events, a statistically significant difference was identified for ammonia, total phosphorus, phosphate, total nitrogen, and nitrate. All of these pollutants occurred at higher concentrations in the wastewater plot runoff when compared to the control plots (Table 6). An estimate of the total runoffload is difficult for 2014 since some of the runoff volumes were not recorded. However, if average runoff volumes are used, the total nitrogen in the runoff would be $0.067 \mathrm{~kg}$ and total phosphorus

Table 4

Pollutant concentrations in a single runoff event from the 2013 irrigation season

(all units are in $\mathrm{mg} / \mathrm{L}$ )

\begin{tabular}{lccccccc}
\hline $\begin{array}{l}\text { Irrigation } \\
\text { treatment }\end{array}$ & $\mathrm{BOD}_{5}$ & $\mathrm{TSS}$ & $\mathrm{NH}_{3}-\mathrm{N}$ & Total-N as $\mathrm{N}$ & Total-P as $\mathrm{P}$ & $\mathrm{PO}_{4}-\mathrm{P}$ & $\mathrm{NO}_{3}-\mathrm{N}$ \\
\hline Water & 10.8 & - & 2.58 & 8.79 & 0.37 & 0.36 & 0.95 \\
$\begin{array}{l}\text { Treated } \\
\text { wastewater }\end{array}$ & - & - & 0.89 & 4.12 & 0.16 & 0.02 & 0.49 \\
\hline
\end{tabular}


Table 5

Pollutant concentrations in plot runoff from the 2014 irrigation season

\begin{tabular}{|c|c|c|c|c|c|c|c|c|c|c|}
\hline $\begin{array}{l}\text { Sample } \\
\text { date }^{\wedge}\end{array}$ & $\begin{array}{l}\mathrm{BOD}_{5} \\
(\mathrm{mg} / \mathrm{L})\end{array}$ & $\begin{array}{l}\text { E. coli } \\
\text { (cfu/100 mL) }\end{array}$ & $\begin{array}{l}\text { TSS } \\
(\mathrm{mg} / \mathrm{L})\end{array}$ & $\begin{array}{l}\text { Total-N } \\
\text { as N } \\
(\mathrm{mg} / \mathrm{L})\end{array}$ & $\begin{array}{l}\text { Total-P } \\
\text { as P } \\
(\mathrm{mg} / \mathrm{L})\end{array}$ & $\begin{array}{l}\mathrm{PO}_{4}-\mathrm{P} \\
(\mathrm{mg} / \mathrm{L})\end{array}$ & $\begin{array}{c}\mathrm{NH}_{3}-\mathrm{N} \\
(\mathrm{mg} / \mathrm{L})\end{array}$ & $\begin{array}{c}\mathrm{NO}_{3}-\mathrm{N} \\
(\mathrm{mg} / \mathrm{L})\end{array}$ & $\begin{array}{c}\text { Runoff } \\
\text { volume } \\
\text { (L) }\end{array}$ & $(\mathrm{mm})$ \\
\hline \multicolumn{11}{|c|}{ Wastewater plot 1} \\
\hline $2 / 20 / 14$ & 5.2 & 50 & 272 & 3.03 & 1.38 & 0.49 & 0.92 & 0.93 & 4027 & 3.61 \\
\hline $3 / 3 / 14$ & 3.0 & - & 51 & 7.24 & 1.18 & 1.22 & 2.18 & 5.33 & 494 & 0.44 \\
\hline $3 / 5 / 14$ & 7.4 & - & 43 & 7.32 & 1.41 & 1.27 & 1.77 & 4.7 & 458 & 0.41 \\
\hline $3 / 7 / 14$ & 6.3 & 5 & 40 & 5.30 & 0.8 & 0.75 & 1.92 & 2.66 & $\#$ & \\
\hline \multicolumn{11}{|c|}{ Wastewater plot 2} \\
\hline $2 / 3 / 14$ & 4.7 & 75 & 569 & 6.34 & 1.71 & 1.48 & 2.05 & 2.24 & 561 & 0.38 \\
\hline $2 / 20 / 14$ & 6.2 & 70 & 283 & 4.63 & 1.52 & 1.13 & 1.71 & 1.52 & $\#$ & \\
\hline $2 / 22 / 14$ & 3.4 & 100 & 268 & 1.76 & 1.15 & 0.21 & 0.11 & 0.84 & 249 & 0.17 \\
\hline $3 / 3 / 14$ & 4.2 & - & 38 & 5.58 & 0.98 & 0.85 & 1.82 & 2.38 & \# & \\
\hline $3 / 5 / 14$ & 7 & - & 43 & 7.59 & 1.46 & 1.42 & 2.43 & 5.01 & \# & \\
\hline $3 / 6 / 14$ & 7.2 & - & 66 & 8.00 & 1.99 & 2.02 & 3.12 & 10.3 & \# & \\
\hline $3 / 7 / 14$ & 9.2 & 5 & 43 & 6.31 & 2.22 & 2.32 & 3.23 & 7.74 & $\#$ & \\
\hline $3 / 8 / 14$ & 7.1 & 5 & 74 & 4.98 & 0.84 & 0.66 & 1.99 & 1.26 & 249 & 0.17 \\
\hline Average* & 5.9 & 23 & 149 & 5.67 & 1.39 & 1.15 & 1.94 & 3.74 & 1006 & \\
\hline$n=$ & 12 & 7 & 12 & 12 & 12 & 12 & 12 & 12 & 6 & \\
\hline \multicolumn{11}{|l|}{ Control plot 1} \\
\hline $12 / 21 / 14$ & - & - & 722 & 2.91 & 0.89 & 0.59 & 0.03 & 1.27 & 81 & 0.07 \\
\hline $2 / 3 / 14$ & 4.3 & 120 & 443 & 1.21 & 1.25 & 0.69 & 0.48 & 0.84 & 77 & 0.07 \\
\hline $2 / 20 / 14$ & 5.3 & 30 & 262 & 1.82 & 1.11 & 0.15 & 0.19 & 0.62 & $\#$ & \\
\hline $4 / 7 / 14$ & 3.9 & 118 & 106 & 0.99 & 0.31 & 0.31 & 0.82 & 0.00 & $\#$ & \\
\hline $4 / 11 / 14$ & 16.1 & 0 & 208 & 2.89 & 0.39 & 0.42 & 1.65 & 0.07 & 121 & 0.11 \\
\hline \multicolumn{11}{|l|}{ Control plot 2} \\
\hline $12 / 21 / 14$ & - & - & 1061 & 3.41 & 1.09 & 0.79 & 0.16 & 1.36 & 101 & 0.07 \\
\hline $2 / 3 / 14$ & 12 & 10 & 448 & 4.11 & 1.42 & 0.98 & 0.96 & 2.19 & 34 & 0.02 \\
\hline $2 / 20 / 14$ & 5.8 & 85 & 268 & 2.09 & 1.12 & 0.21 & 0.35 & 0.83 & 3310 & 2.23 \\
\hline $2 / 22 / 14$ & 4.6 & 0 & 290 & 1.29 & 1.13 & 0.13 & 0.16 & 0.58 & 736 & 0.19 \\
\hline $3 / 7 / 14$ & 8 & 5 & 46 & 0.02 & 0.79 & 0.75 & 2.04 & 0.73 & 124 & 0.08 \\
\hline $3 / 8 / 14$ & 8.4 & 60 & 72 & 0.02 & 0.82 & 0.66 & 1.42 & 0.03 & 778 & 0.52 \\
\hline $4 / 7 / 14$ & 12.9 & 808 & 204 & 2.36 & 0.55 & 0.6 & 1.41 & 0.07 & $\#$ & \\
\hline $4 / 11 / 14$ & 12.8 & 0 & 313 & 1.61 & 0.59 & 0.67 & 1.97 & 0.25 & 222 & 0.15 \\
\hline Average* & 8.5 & 19 & 341 & 1.90 & 0.88 & 0.53 & 0.89 & 0.68 & 620 & \\
\hline$n=$ & 11 & 11 & 13 & 13 & 13 & 13 & 13 & 13 & 9 & \\
\hline $\begin{array}{l}\text { *All averages } \\
\text { \# Flow meter } \\
\text { ^D Duplicate }\end{array}$ & $\begin{array}{l}\text { re arith } \\
\text { ng equi } \\
\text { mpling }\end{array}$ & tic means & pt for & coli whic & $\begin{array}{l}s \text { a geome } \\
\text { ues for ru }\end{array}$ & $\begin{array}{l}\text { ic mean } \\
\text { fff volum }\end{array}$ & 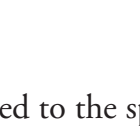 & . & ment & \\
\hline
\end{tabular}


Table 6

Statistical comparison of 2014 average runoff pollutant concentrations from the wastewater irrigated and control plots

(Significant differences $(\alpha=0.05)$ are identified in bold)

\begin{tabular}{lcccccccc}
\hline \hline & $\begin{array}{c}\mathrm{BOD}_{5} \\
(\mathrm{mg} / \mathrm{L})\end{array}$ & $\begin{array}{c}\mathrm{TSS} \\
(\mathrm{mg} / \mathrm{L})\end{array}$ & $\begin{array}{l}\text { E. coli } \\
(\mathrm{cfu} / 100 \mathrm{~mL})\end{array}$ & $\begin{array}{c}\mathrm{NH}_{3}-\mathrm{N} \\
(\mathrm{mg} / \mathrm{L})\end{array}$ & $\begin{array}{c}\text { Total-N as N } \\
(\mathrm{mg} / \mathrm{L})\end{array}$ & $\begin{array}{c}\text { Total-P as } \mathrm{P} \\
(\mathrm{mg} / \mathrm{L})\end{array}$ & $\begin{array}{c}\mathrm{PO}_{4}-\mathrm{P} \\
(\mathrm{mg} / \mathrm{L})\end{array}$ & $\begin{array}{c}\mathrm{NO}_{3}-\mathrm{N} \\
(\mathrm{mg} / \mathrm{L})\end{array}$ \\
\hline Wastewater plot & 5.9 & 149 & 23 & $\mathbf{1 . 9 4}$ & $\mathbf{5 . 6 7}$ & $\mathbf{1 . 3 9}$ & $\mathbf{1 . 1 5}$ & $\mathbf{3 . 7 4}$ \\
Control plot & 8.5 & 341 & 19 & $\mathbf{0 . 8 9}$ & $\mathbf{1 . 9}$ & $\mathbf{0 . 8 8}$ & $\mathbf{0 . 5 3}$ & $\mathbf{0 . 6 8}$ \\
p-value & 0.079 & 0.063 & 0.81 & $\mathbf{0 . 0 0 3}$ & $\mathbf{4 . 4 0 E - 0 6}$ & $\mathbf{0 . 0 0 3 7}$ & $\mathbf{0 . 0 0 5 7}$ & $\mathbf{0 . 0 0 4}$ \\
*All means are arithmetic means except for E. coli which is a geometric mean & &
\end{tabular}

$0.02 \mathrm{~kg}$ in a severe winter. These values represent $92 \%$ total nitrogen removal and $95 \%$ total phosphorus removal of what was applied. It is important to note that all of the total nitrogen and phosphorus would have been discharged under an NPDES permitted discharging system.

\section{DISCUSSION}

The two winters offered unique insight into the implications of irrigating reclaimed wastewater in cold temperatures. The winter of 2013 was close to a normal winter. Precipitation was $32.3 \mathrm{~mm}$ lower than normal and high intensity events were not observed. The monthly temperatures in January and February were slightly warmer and slightly colder than normal, respectively. In contrast, the severe winter of 2014 was marked by temperatures that were much colder than normal especially the months of January and February. Two air freezing events were 17 days long and were also only separated by a single day. The thaw was not complete between these events, resulting in effectively one air freezing event extending for 35 days.

The key difference in weather was freezing event duration, which became especially apparent when observing soil freezing throughout the winter. During the first winter, the soils only exhibited freezing in late January. Conversely, the second winter was severe and was dominated by frozen soils with the first freezing event occurring in early January. A second soil freezing event began January 23 and persisted for an entire month. The final soil freezing event occurred in late February persisting through early March with no snow cover. The lack of snow cover resulted in soils freezing deeper.

The timing of the runoff events that were observed during the two winters demonstrated that frozen soils correlated with increased runoff events. However, runoff did not occur during irrigation. During freezing events the irrigated water or wastewater contributed to a snow or ice pack and accumulated on the surface as shown in Fig. 7.

The critical condition was when the snow and ice

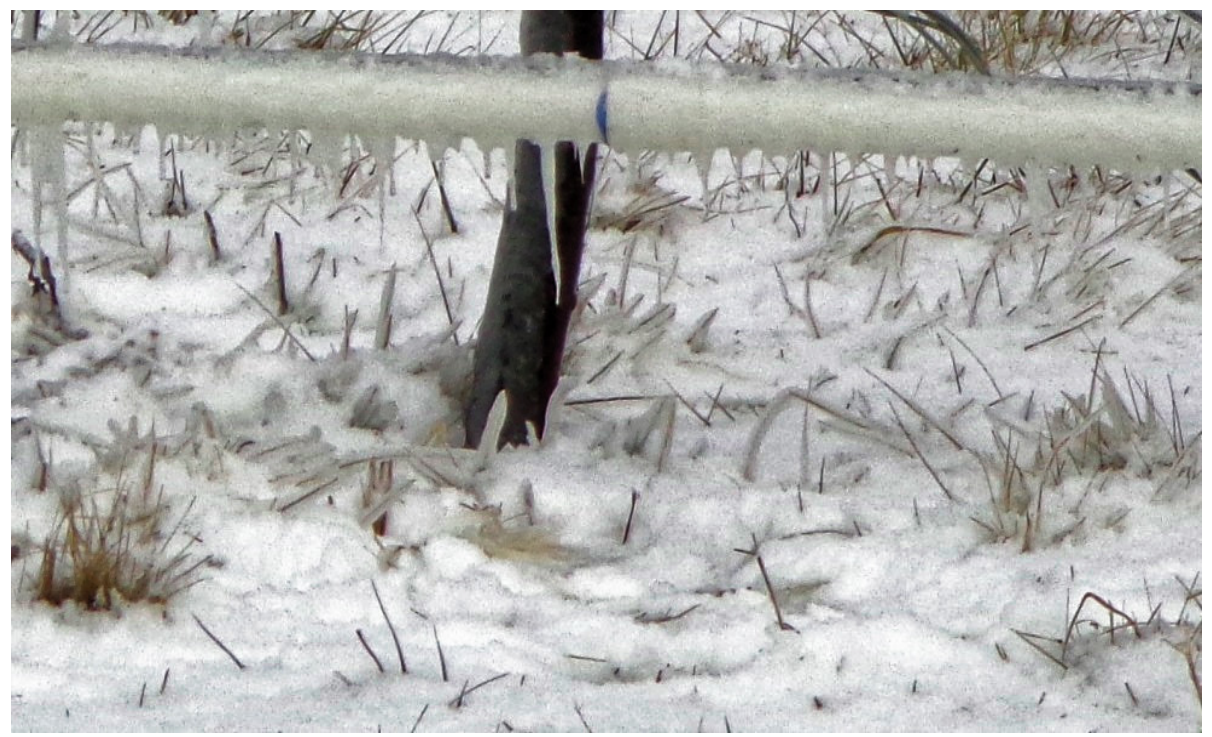

FIGURE 7. Ice accumulation on irrigation pipe and grass 
pack melted. If the snow melt occurred slowly, and the soils underneath were either unfrozen or partially frozen, infiltration occurred. However, if the snow and ice melted rapidly, especially with additional precipitation, runoff was almost always the result. The observations are consistent with those from a similar study in Vermont (Jewell and Swan 1975).

Four of the water quality parameters in this study are pollutants regulated for discharging household sewage treatment systems under the general permit issued by Ohio EPA (Ohio EPA 2014). These are $\mathrm{CBOD}_{5}(15$ $\mathrm{mg} / \mathrm{L})$, E. coli $(530 \mathrm{cfu} / 100 \mathrm{~mL})$, filterable residuetotal suspended solids (18 mg/L), and ammonia (4.5 $\mathrm{mg} / \mathrm{L})$. Of the regulated pollutants, only suspended solids in the runoff exceeded the Ohio EPA effluent standards. While suspended solids did runoff, the concentrations were not significantly different for the control compared to the wastewater irrigated treatment. Ammonia, although within Ohio EPA discharge limits, was observed in higher concentrations from the wastewater irrigated plots.

Other parameters that had significant differenceswere soluble nutrients, which were at high concentrations in the simulated wastewater that was used for irrigation. These water quality parameters were detected at higher levels in the runoff from plots with treated wastewater applications than the control plots. However, the runoff total $\mathrm{P}$ concentration was $31 \%$ of the concentration discharged to the soil and total $\mathrm{N}$ concentration was $41 \%$ of the concentration discharged to the soil. When compared to the total nitrogen and phosphorus load applied, the irrigation system achieved higher than $90 \%$ removal in both normal and severe winters.

\section{CONCLUSION AND RECOMMENDATIONS}

Weather data showed that the winter irrigation experiments occurred in a near-normal winter in 2013 and a severe winter in 2014. In 2014, the weather was much colder than normal and the beginning and end of the winter were wet. The two winters offered unique insight to the impacts of weather variability on wastewater application in cold weather.

Based on the soil moisture sensor data and visual observations, the soil in the irrigation plots did not freeze completely and remained permeable to applied water in the 2013 irrigation season, even though they were exposed to sub-freezing temperatures. As a result, neither the irrigation nor precipitation resulted in runoff. The 2014 season had longer duration freezing events that led to times of complete soil freezing. Even in this condition irrigated water served only to add to the snow/ice pack (Fig. 7). Runoff only occurred during snow/ice melt. During the most complete freeze of the plots, when no snow cover was present, the irrigated wastewater had a more appreciable impact on runoff yield and quality.

The infiltrative capacity of the plots was maintained during the 2013 season, which, coupled with low intensity precipitation events, yielded runoff on only one day. However, the severe winter in 2014 caused runoff on 11 days. Ammonia was the only regulated pollutant to have a significantly higher average runoff concentration from the wastewater plots compared to the control plots (Table 6). However, the volume of water that ran off was much less than the volume of water that was applied to the plots. Also, the concentrations of the pollutants in the runoff were lower than what was applied and were less than the Ohio EPA effluent limits. The indication is that even in the worst-case scenario most of the pollutants were assimilated on site.

\section{ACKNOWLEDGEMENTS}

This research was funded in part by the Ohio Department of Health. Salary and partial research support to Karen M. Mancl were provided by state and federal (USDA-NIFA) funds appropriated to the Ohio Agricultural Research and Development Center. Additional research support from the Baas Memorial Endowment Fund is gratefully acknowledged. We thank Christopher Gesik, Jim Bonta, Jim Buxton, and Will Dreher for their help in setting up and managing the field monitoring site.

\section{LITERATURE CITED}

Caldwell H, Mancl K, Quigley MF. 2007. The effects of yearround irrigation on landscape plant quality and health in Ohio. Ohio J Sci. 107(4):76-81.

Clesceri LS, Greenberg AE, Eaton AD. 1998. Standard methods for the examination of water and wastewater. 20th Edition. American Public Health Association.

Decagon Devices Inc. 2014. EC-5 soil moisture sensor operator's manual. Available from: manuals.decagon.com/ Manuals/13876_EC-5_Web.pdf.

Gunn KM, Mancl KM. 2011. Investigating methods for preventing cold induced freezing of irrigation sprinklers. Appl Eng Agr. 27(2):253-260. Available from: http://dx.doi. org/ $10.13031 / 2013.36493$.

Hu C, Zhang TC, Huang YH, Dahab MF, Surampalli R. 2005. Effects of long-term wastewater application on chemical properties and phosphorus adsorption capacity in soils of a wastewater land treatment system. Environ Sci Technol. 39(18):7240-7245. Available from: http://dx.doi. org/10.1021/es050526p. 
Jewell WJ, Swan R. 1975. Spray disposal of treated domestic wastewater on upland fragipan soils in a severe winter climate. Water Pollution Control in Low Density Areas - Proceedings of a Rural Environmental Engineering Conference. Hanover, New Hampshire. University Press of New England. Pages 15-22.

Ohio EPA. 2014. Ohio Environmental Protection Agency General Permit Authorization to Discharge Wastewater from Selected New, Replacement and/or Updated Household Sewage Treatment Systems Under the National Pollutant Discharge Elimination System. Available from: http://epa.ohio.gov/ portals/35/permits/OHK00003-FINAL\%20PERMIT.pdf.

Rowan M, Mancl K, Caldwell H. 2004. On-site sprinkler irrigation of treated wastewater in Ohio. Bulletin 912-04. Columbus $(\mathrm{OH})$ : The Ohio State University, College of Food, Agricultural, and Environmental Sciences. 35 p.

Sopper WE, Richenderfer JL. 1978. Effects of spray irrigation of municipal wastewater on the physical properties of soil. Institute for Research on Land and Water Resources. University Park(PA): The Pennsylvania State University.

USEPA. 1986. Bacteriological ambient water quality criteria for marine and fresh recreational waters. EPA 440/5-84-002. Cincinnati $(\mathrm{OH})$ : U.S. Environmental Protection Agency, Office of Research and Development.

USEPA. 2015. Summary of the clean water act. United States Environmental Protection Agency. Available from. https:// www.epa.gov/laws-regulations/summary-clean-water-act.

Walker C, Lin HS. 2008. Soil property changes after four decades of wastewater irrigation: A landscape perspective. Catena. 73(1):63-74. Available from: http://dx.doi.org/10.1016/j. catena.2007.09.002. 